\title{
EDUKASI POLA MAKAN SEHAT DALAM UPAYA PENGENDALIAN HIPERTENSI DI MASA PANDEMI COVID-19
}

\author{
Meilani Kumala ${ }^{1}$, Dorna Yanti Lola Silaban ${ }^{2}$, Frisca $^{3}$, dan Alexander Halim Santoso ${ }^{4}$
}

\author{
${ }^{1}$ Bagian Ilmu Gizi, Fakultas Kedokteran, Universitas Tarumanagara Jakarta \\ Email: melkum58@yahoo.com \\ ${ }^{2}$ Bagian Ilmu Gizi, Fakultas Kedokteran, Universitas Tarumanagara Jakarta \\ Email: dorna@fk.untar.ac.id \\ ${ }^{3}$ Bagian Ilmu Gizi, Fakultas Kedokteran, Universitas Tarumanagara Jakarta \\ Email: natfrisca@gmail.com \\ ${ }^{4}$ Bagian Ilmu Gizi, Fakultas Kedokteran, Universitas Tarumanagara Jakarta \\ Email: alexanders@fk.untar.ac.id
}

\begin{abstract}
Hypertension is a non-communicable disease (NCD) with a high prevalence in both developed and developing countries, including Indonesia. Riskesdas 2018 shows the prevalence of hypertension in 2018 is increased by $8.3 \%$ compared to 2013. Studies that have been conducted shows that sufferers of Corona-19 virus infection (COVID-19) have been increased in severity when accompanied by hypertension. The first case of COVID-19 in Indonesia was found in DKI Jakarta. The area of Tomang urban village is one of the 25th urban villages with the highest number of Covid-19 cases in Jakarta. Among other NCDs, hypertension and diabetes mellitus are found in high numbers in Tomang, West Jakarta. According to this condition, preventive efforts are needed to reduce the high risk of complications in NCDs sufferers such as hypertension, in the Tomang area, West Jakarta. Appropriate dietary intake, including balanced nutrition and adequate fluid intake, is one of the ways to control hypertension and increase immunity. As a concrete action in raising awareness to the community in Tomang Village, West Jakarta, education has been carried out regarding the pattern of healthy and balanced diet as an effort to prevent and control hypertension and also prevent COVID-19. The results of these educational activities based on the pre-post test showed that most of them had increased knowledge about healthy food intake and balanced nutrition after receiving this education. A regular education to the public is needed regarding a balanced nutritional diet including an appropriate food intake pattern in controlling hypertension and efforts to increase immunity.
\end{abstract}

Keywords: hypertension, COVID-19, healthy food pattern, balanced nutrition.

\begin{abstract}
ABSTRAK
Hipertensi merupakan salah satu penyakit tidak menular (PTM) dengan angka kejadian yang tinggi baik di negara maju maupun negara sedang berkembang termasuk Indonesia. Data Riskesdas 2018, didapatkan peningkatan angka kejadian hipertensi sebesar 8,3\% dibandingkan angka kejadian hipertensi pada tahun 2013. Penelitian yang telah dilakukan menunjukkan penderita infeksi virus Corona-19 (COVID-19) tingkat keparahan meningkat bila disertai hipertensi. Kasus pertama COVID-19 di Indonesia ditemukan di DKI Jakarta. Wilayah kelurahan Tomang yang merupakan daerah mitra FK Untar termasuk dalam 25 kelurahan dengan jumlah kasus tertinggi Covid-19 di Jakarta. Angka kejadian hipertensi serta DM di kelurahan Tomang, Jakarta Barat, didapatkan merupakan penyakit yang cukup tinggi diantara PTM lainnya. Untuk itu perlu dilakukan upaya preventif untuk menurunkan risiko komplikasi yang tinggi pada penderita PTM seperti hipertensi, di wilayah Tomang Jakarta Barat. Asupan makanan dengan pola makanan sehat, bergizi mencakup gizi seimbang dan aman serta asupan cairan yang sesuai kebutuhan adalah salah satu langkah untuk mengendalikan hipertensi dan meningkatkan kekebalan tubuh. Sebagai bentuk nyata untuk meningkatkan kesadaran kepada msayarakat di kelurahan Tomang Jakarta Barat, telah dilakukan edukasi mengenai pola asupan makanan sehat dan seimbang sebagai salah satu upaya pencegan dan pengendalian hipertensi dan pencegahan COVID-19. Hasil kegiatan edukasi tersebut berdasarkan pre-pos tes menunjukkan sebagian besar terdapat peningkatan pengetahuan tentang asupan makanan sehat dan gizi seimbang setelah mendapat edukasi. Perlu dilakukan edukasi secara rutin kepada masyarakat terkait pola makan gizi seimbang merupakan pola asupan makanan yang sesuai dalam mengendalikan hipertensi dan upaya meningkatkan kekebalan tubuh.
\end{abstract}

Kata kunci: hipertensi, COVID-19, pola makanan sehat, gizi seimbang.

\section{PENDAHULUAN}

Hipertensi merupakan salah satu penyakit tidak menular (PTM) dengan angka kejadian yang tinggi baik di negara maju maupun negara sedang berkembang termasuk Indonesia. Selain penyakit infeksi menular, saat ini Indonesia mengalami peningkatan PTM meliputi hipertensi. Data di Indonesia berdasarkan Riset Kesehatan Dasar 2013 menunjukkan terdapat peningkatan PTM 
dibandingkan kejadian PTM pada tahun 2007 (Riset Kesehatan Dasar [Riskesdas], 2013). Berdasarkan data Riskesdas 2018, didapatkan peningkatan angka kejadian hipertensi sebesar 8,3\% dibandingkan angka kejadian hipertensi pada tahun 2013. (Riskesdas, 2018) Data monitor kemajuan PTM 2017 menunjukkan bahwa angka kematian dan risiko kematian masyarakat akibat PTM termasuk hipertensi di Indonesia cukup tinggi mencapai 73\% (World Health Organization [WHO], 2017).

Berbagai penelitian akhir-akhir ini menunjukkan terdapat hubungan antara Hipertensi dengan Coronavirus disease 19 (COVID-19), suatu penyakit yang ditetapkan oleh World Health Organization (WHO) sebagai pandemi termasuk di Indonesia. Bulan Maret dan Juni tahun 2020 di Indonesia, pada Provinsi Daerah Khusus Ibukota (DKI) Jakarta dan Jawa Timur merupakan episentrum kasus COVID-19. Infeksi Corona Virus merupakan jenis infeksi saluran pernapasan terbaru COVID-19 dengan gejala flu hingga keadaan yang lebih parah seperti pada Middle East Respiratory Syndrome (MERS-CoV) dan Severe Acute Respiratory Syndrome (SARS-CoV) (Wenzel RP, 2003). Pada kasus yang lebih parah, infeksi dapat menyebabkan pneumonia, sindrom pernapasan akut, gagal ginjal, dan bahkan kematian (World Health Report, 2020). Corona virus masuk ke dalam tubuh melalui mekanisme mengikat Angiotensin Converting Enzyme 2 (ACE2) sebagai reseptor untuk memfasilitasi masuknya dan replikasi virus dalam organ tubuh seperti paru. ACE2 mempunyai peran mengkatalisasi hidrolisis angiotensin-II (Ang-II) yang bersifat vasokonstriksi menjadi angiotensin (1-7) yang bersifat vasodilatasi (Huang, 2020). Terikatnya Corona virus pada ACE2 menyebabkan menurunnya fungsi ACE2 yang mengakibatkan menurunnya produksi angiotensin (1-7) dan selanjutnya memengaruhi regulasi tekanan darah. (Ribeiro-Oliveira et al., 2008; Nehme et al., 2019) Berdasarkan peran/aktivitas Corona Virus tersebut, dapat dijelaskan mengapa COVID-19 memengaruhi penderita hipertensi. Pasien COVID19 dengan hipertensi dikaitkan dengan kesehatan yang buruk, lama rawat tinggal di rumah sakit dan masuk dalam perawatan di intensive care unit (ICU). Pada orang yang sudah mengalami hipertensi bila terserang COVID-19 akan mengalami keparahan, mengalami kematian sebesar 2,5 kalinya (Huang, 2020; Tignanelli et al., 2020).

Pencegahan dan pengendalian Hipertensi selama masa pandemi COVID-19 perlu dilakukan. Faktor risiko hipertensi diduga sebagai akibat adanya perubahan gaya hidup meliputi asupan pola makanan siap saji yang tinggi gula, garam, dan lemak; konsumsi rokok; alkohol serta kurangnya aktivitas fisik (Ige et al., 2013; Sandhu et al., 2015). Oleh karena itu mengonsumsi makanan sehat merupakan hal yang perlu dilakukan dalam pencegahan dan pengendalian hipertensi. Pola makan gizi seimbang merupakan pola asupan makanan yang sesuai dalam mengendalikan hipertensi (Kementrian Kesehatan Republik Indonesia [Kemkes RI], 2014). Selain pengendalian hipertensi, mencegah terinfeski COVID-19 perlu dilakukan oleh masyarakat. Pencegahan COVID-19 dilakukan dengan gerakan pakai masker, jaga jarak, cuci tangan, dan juga perlu meningkatkan kekebalan/daya tahan tubuh. Upaya yang perlu dilakukan untuk meningkatkan kekebalan tubuh merupakan salah satu langkah untuk mencegah atau mengurangi risiko mengalami gangguan kesehatan atau keparahan ketika terserang COVID-19. Asupan makanan dengan pola makanan sehat, bergizi mencakup gizi seimbang dan aman serta asupan cairan yang sesuai kebutuhan adalah salah satu langkah untuk meningkatkan kekebalan tubuh (Kemkes RI, 2020).

Upaya pencegahan dan pengendalian hipertensi serta pencegahan COVID-19 perlu dilakukan oleh masyarakat agar dapat tetap sehat di masa pandemi COVID-19 ini. Untuk itu Perlu dilakukan kegiatan edukasi kepada masyarakat untuk mengingatkan, mengaktivasi prilaku dan menciptakan suasana yang sehat dalam masa pandemi ini. Wilayah kelurahan Tomang merupakan daerah binaan Fakultas Kedokteran Universitas Tarumanagara serta daerah Tomang termasuk dalam zona 
merah Covid. Berdasarkan permasalahan yang diuaraikan di atas maka dilakukan upaya preventif untuk menurunkan resiko komplikasi yang tinggi pada penderita PTM seperti hipertensi dan DM di wilayah Tomang Jakarta Barat. Sebagai bentuk nyata telah dirancang edukasi dalam bentuk penyuluhan terkait pola makan sehat dalam upaya pengendalian hipertensi di masa pandemi covid19 kepada para kader kelurahan Tomang, Jakarta Barat.

\section{Permasalahan Mitra}

Kasus pertama COVID-19 di Indonesia ditemukan di DKI Jakarta dengan jumlah kasus COVID19 yang lebih tinggi terkait dengan mobilitas penduduk yang tinggi. Survei sebelumnya pada tahun 2019 tercatat 1,2 juta orang berkunjung ke DKI Jakarta setiap hari. (Peta Sebaran, 2020; Survei Komputer Jabodetabek, 2019). Wilayah kelurahan Tomang merupakan daerah binaan Fakultas Kedokteran Universitas Tarumanagara. Kelurahan Tomang termasuk dalam 25 kelurahan dengan jumlah kasus tertinggi Covid-19 di Jakarta (data kelurahan). Data angka kejadian penderita hipertensi serta DM di Tomang, Jakarta Barat didapatkan merupakan penyakit yang cukup tinggi diantara PTM lainnya (Santoso et al., 2020). Berdasarkan permasalahan yang diuraikan di atas maka perlu dilakukan upaya preventif untuk menurunkan risiko komplikasi yang tinggi pada penderita PTM seperti hipertensi, di wilayah Tomang Jakarta Barat.

\section{METODE PELAKSANAAN PKM Persiapan pelaksanaan}

Persiapan pelaksanaan kegiatan PKM di kelurahan Tomang, Jakarta Barat dilakukan dalam beberapa tahap meliputi:

- Persiapan awal pelaksanaan kegiatan PKM: Eksplorasi tingkat prevalensi hipertensi dan COVID-19 berdasarkan survei dan bukti/data kegiatan PKM dan penelitian sebelumnya,

- Survei lapangan: survei ke kantor kelurahan Tomang, Jakarta Barat (melalui zoom) untuk mendapatkan data terkait permasalahan kesehatan termasuk penyakit tidak menular dan COVID-19,

- Penyusunan Proposal: berdasarkan data dari hasil survei disusun proposal, topik dan pembicara yang sesuai topik permasalahan,

- Rancangan pelaksanaan: rancangan materi pre/pos tes sebagai umpan balik dari kegiatan PKM,

- Rapat persiapan finalisasi hari pelaksanaan, pelaksanaan dan rapat evaluasi pelaksanaan.

\section{Alur pelaksanaan kegiatan}

Pelaksanaan PKM dilakukan melalui zoom dengan alur pelaksanaan seperti pada Gambar 1. Pada hari kegiatan, acara dimulai dengan sambutan pihak kelurahan dan pihak FK Untar dilanjutkan dengan pre tes untuk mengetahui tingkat pengetahuan mengenai materi yang akan disampaikan. Kegiatan dilanjutkan dengan penyampaian materi dari nara sumber dan sebelum kegiatan berakhir dilakukan pos tes dengan tujuan mengetahui capaian pengetahuan dari para kader setelah mendapat materi.

\section{HASIL DAN PEMBAHASAN}

Kegiatan pengabdian kepada masyarakat dengan topik "Edukasi Pola Makan Sehat Dalam Upaya Pengendalian Hipertensi di Masa Pandemi Covid-19" telah dilaksanakan pada hari selasa, 15 Desember 2020. Kegiatan ini diikuti oleh 37 peserta yang terdiri dari para kader dari Kelurahan Tomang Jakarta Barat, perwakilan dari posyandu kelurahan dan perwakilan Karang Taruna. Pelaksanaan edukasi di awali dengan pre tes sebanyal 10 soal. 


\section{Gambar 1}

\section{Alur Pelaksanaan PKM}

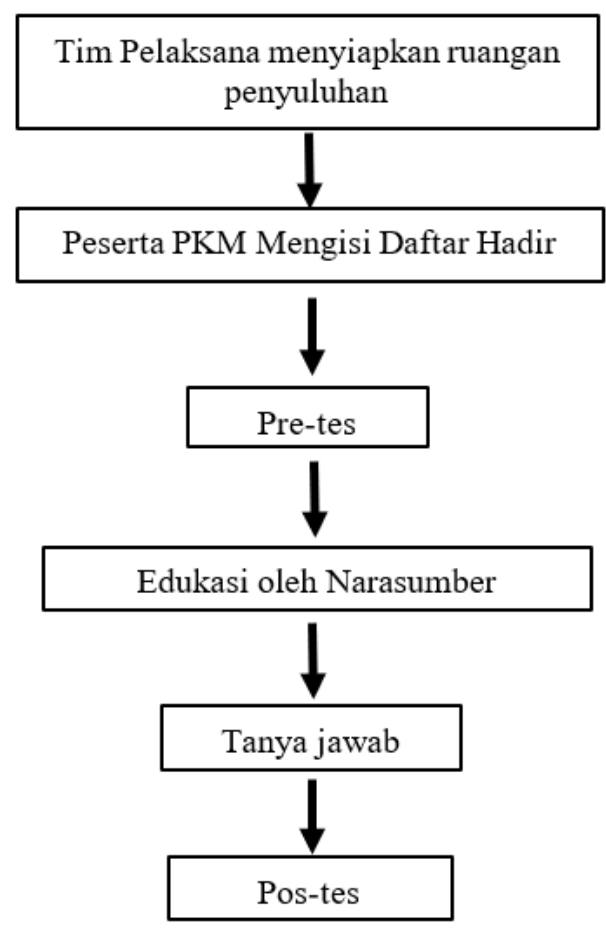

Hasil pre-tes menunjukkan tidak ada yang mengetahui dengan tepat anjuran jumlah maksimal gula yang dapat dikonsumsi dalam sehari, terdapat $72,4 \%$ yang mengetahui anjuran jumlah maksimal garam yang dapat dikonsumsi dalam sehari dan $93,1 \%$ peserta mengetahui anjuran jumlah maksimal minyak yang dapat dikonsumsi dalam sehari. Hasil pre-test juga menunjukkan sebanyak $65,5 \%$ peserta mengetahui jumlah porsi sayur yang dianjurkan untuk dikonsumsi dalam sehari dan $51,7 \%$ peserta mengetahui jumlah porsi buah yang dianjurkan untuk dikonsumsi dalam sehari. Lebih dari separuh peserta $(79,3 \%)$ mengetahui makanan-makanan yang sebaiknya dihindari agar terhindar dari penyakit darah tinggi, namun hanya $20,7 \%$ peserta yang mengetahui proses pengolahan makanan yang sebaiknya dihindari untuk mencegah penyakit tidak menular.

Pada saat dilakukan edukasi, pemateri menjelaskan mengenai hipertensi meliputi prevalensi, faktor risiko, dampak, pencegahan dan pengendalian hipertensi. Faktor risiko hipertensi diduga sebagai akibat adanya perubahan gaya hidup meliputi asupan pola makanan siap saji yang tinggi gula, garam, dan lemak; konsumsi rokok; alkohol serta kurangnya aktivitas fisik. Pola makan gizi seimbang merupakan pola asupan makanan yang sesuai dalam mencegah dan mengendalikan hipertensi. Selain itu, juga dibahas mengenai pencegahan COVID-19 antara lain untuk diri sendiri, di tempat umum, bagi pekerja, pengunjung pasar, dan pusat perbelanjaan. Pencegahan COVID-19 dilakukan dengan gerakan pakai masker, jaga jarak, cuci tangan, dan juga perlu meningkatkan kekebalan/daya tahan tubuh. Asupan makanan dengan pola makanan sehat, bergizi mencakup gizi seimbang dan aman serta asupan cairan yang sesuai kebutuhan adalah salah satu langkah untuk meningkatkan kekebalan tubuh. Untuk memudahkan kepada peserta mengingat makanan yang sehat yang harus dikonsumsi oleh masyarakat agar dapat mencegah dan mengendalikan hipertensi dan juga untuk meningkatkan daya tahan tubuh semasa pandemi COVID 19 ini pada saat edukasi ditayangkan juga flyer (seperti pada Gambar 2) dan contoh-contoh bahan makanan sumber. 


\section{Gambar 2}

\section{Flyer Makanan Sehat}

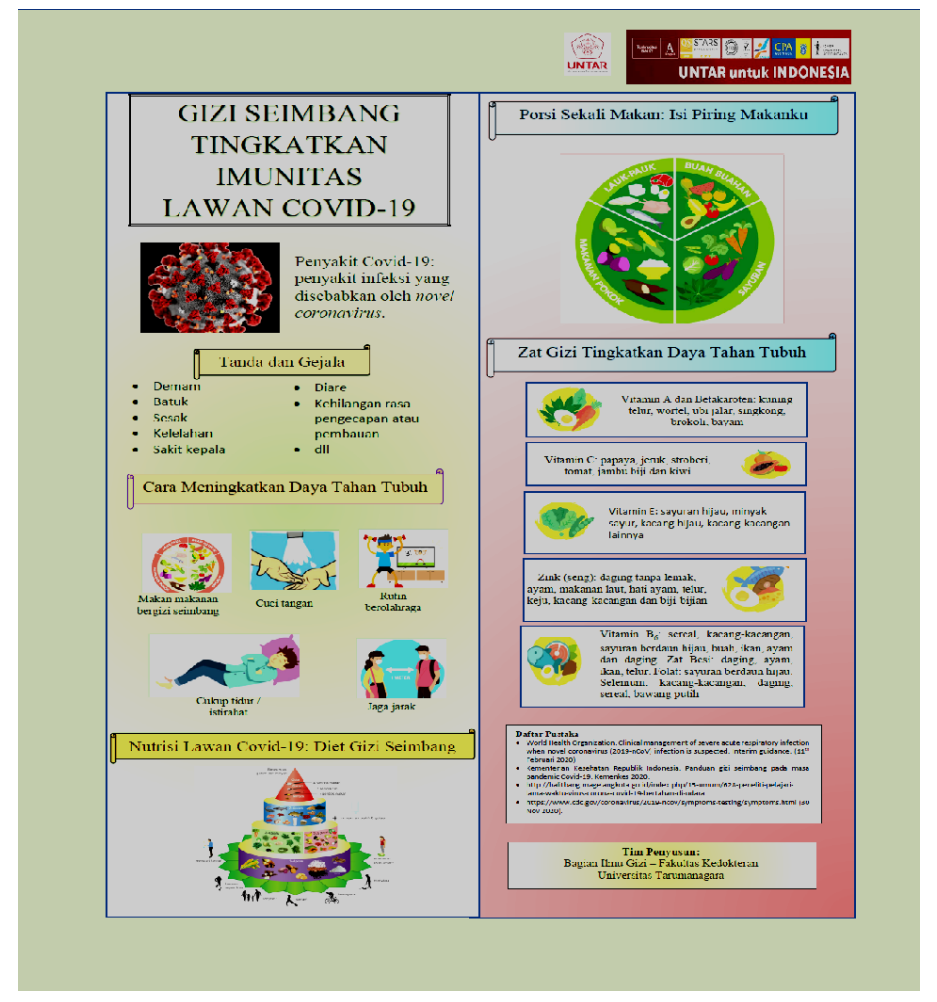

Flyer makanan sehat yang disampaikan pada edukasi memberi arahan kepada para kader antara lain mengonsumsi makanan dengan panduan gizi seimbang untuk meningkatkan imunitas tubuh. Setelah dilakukan edukasi oleh pemateri, kepada peserta dilakukan pos tes dengan soal yang sama Hasil pos-tes menunjukkan bahwa ada peningkatan pengetahuan peserta tentang pola makan yang sehat untuk mengendalikan penyakit tidak menular yang ditunjukkan dengan meningkatnya pengetahuan tentang anjuran asupan gula dalam sehari (0\% menjadi $28 \%)$, anjuran asupan garam dalam sehari $(72,4 \%$ menjadi $96 \%)$, porsi buah yang dianjurkan untuk dikonsumsi dalam sehari (51\% menjadi 52\%), porsi sayur yang dianjurkan untuk dikonsumsi dalam sehari (64\% menjadi $65,5 \%)$, makanan yang sebaiknya dihindari agar terhindar dari penyakit darah tinggi (79,3\% menjadi $92 \%)$ dan proses pengolahan makanan yang sebaiknya dihindari $(20,7 \%$ menjadi $32 \%)$. Terdapat penurunan untuk anjuran asupan minyak dalam sehari (93,1\% menjadi 84\%).

Hasil pre-pos tes tersebut dapat disebabkan jumlah peserta yang memberikan jawaban pada pos tes berkurang sehingga memberikan data yang kurang tepat dibandingkan hasil pre tes. Selain itu beberapa peserta tidak dapat mengingat secara tepat jumlah yang seharusnya karena anjurananjuran yang diberikan banyak dalam bentuk angka (jumlah). Namun pada saat diskusi yang dilakukan setelah penyuluhan, pada prinsipnya peserta sudah dapat mengetahui jenis makananmakanan apa saja yang sebaiknya ditingkatkan dan yang seharusnya dibatasi agar dapat mencegah dan mengendalikan penyakit tidak menular, terutama pada masa pandemi COVID-19 ini.

\section{KESIMPULAN DAN SARAN}

Hipertensi merupakan komorbiditas dari infeksi COVID-19 yang sedang terjadi saat ini. Pasien COVID-19 disertai adanya hipertensi dikaitkan dengan kesehatan yang buruk, lama rawat tinggal di rumah sakit dan masuk dalam perawatan di intensive care unit (ICU). Pada kegiatan edukasi ini didapatkan belum semua peserta menyadari atau mengetahui perlunya asupan makanan gizi 
seimbang. Setelah dilakukan edukasi terdapat peningkatan pengetahuan tentang gizi seimbang yang ditunjukkan peningkatan sebesar $28 \%$ tentang pengetahuan anjuran asupan gula dalam sehari, sebesar 23,6\% mengenai anjuran asupan garam, sebesar 12,7\% makanan yang dihindari untuk mengendalikan penyakit darah tinggi dan 11,3\% untuk proses pengolahan makanan yang sebaiknya dihindari. Berdasarkan hasil kegiatan PKM ini disarankan perlu dilakukan edukasi secara rutin kepada masyarakat terkait pola makan gizi seimbang merupakan pola asupan makanan yang sesuai dalam mengendalikan hipertensi dan upaya meningkatkan kekebalan tubuh.

\section{Ucapan Terima Kasih (Acknowledgement)}

Tim PKM mengucapkan terima kasih kepada Yayasan Tarumanagara, Bapak Rektor Universitas Tarumanagara, Ketua Lembaga Penelitian dan Pengabdian kepada Masyarakat Universitas Tarumanagara, dan Pimpinan Fakultas Kedokteran Universitas Tarumanagara atas dukungan yang diberikan mulai dari persiapan sampai penyelenggaraan kegiatan pengabdian ini. Kami juga mengucapkan terima kasih untuk dukungan, bantuan dan kerjasama dari Ibu Lurah dan masyarakat Kelurahan Tomang Jakarta Barat yang sudah berpartisipasi dalam kegiatan ini.

\section{REFERENSI}

Huang, S., Wang, J., Liu, F., Liu, J., Cao, G., Yang C, Liu, W., Tu, C., Zhu, M., \& Xiong, B. (2020). COVID-19 patients with hypertension have more severe disease: A multicenter retrospective observational study. Hypertens Res. https://www.nature.com/articles/s41440020-0485-2

Ige, O. K., Owoaje, E. T., \& Adebiyi, O. A. (2013). Non communicable disease and risky behaviour in an urban university community Nigeria. African Health Sciences, 13(1), 62 67. https://doi.org/10.4314/ahs.v13i1.9

Jayani, D. H. (2020, Januari 1). Seberapa padat penduduk DKI Jakarta 2019?. databoks. https://databoks.katadata.co.id/datapublish/2020/01/21/seberapa-padat-penduduk-dkijakarta-2019

Kementerian Kesehatan Republik Indonesia (Kemenkes RI). (2014). Pedoman umum gizi seimbang.

Kementerian Kesehatan Republik Indonesia (Kemenkes RI). (2020). Panduan gizi seimbang pada masa pandemic Covid-19.

Nehme, A., Zouein, F. A., Zayeri, Z. D., \& Zibara, K. (2019). An update on the tissue renin angiotensin system and its role in physiology and pathology. Journal of Cardiovascular Development and Disease. 6(2), 14. https://doi.org/10.3390/jcdd6020014

Komite Penanganan Covid-19 dan Pemulikan Ekonomi Nasional. (2020). Peta sebaran. Diunduh 13 September 2020

https://covid19.go.id/peta-sebaran

Ribeiro-Oliveira, A., Nogueira, A. I., Pereira, R. M., Boas, W. W. V., dos Santos RAS, e Silva ACS. (2008) The renin-angiotensin system and diabetes: An update. Vasc. Health Risk Manag. 4, 787-803.

Riset Kesehatan Dasar (RISKESDAS). (2013). Badan penelitian dan pengembangan kesehatan, 2013. https://www.kemkes.go.id/resources/download/general/Hasil\%20Riskesdas\% 202013 pdf

Riset Kesehatan Dasar (RISKESDAS). (2018). Badan penelitian dan pengembangan kesehatan, 2013. https://www.kemkes.go.id/resources/download/general/Hasil\%20Riskesdas\% 202013 pdf

Sandhu, S., Chauhan, R., \& Mazta, S. R. (2015). Prevalence of risk factors for noncommunicable diseases in working population. MAMC J Med Sci, 1(2), 101-4. 
Santoso, A. H., Sari, T., \& Gunawan, S. (2020). Pemetaan profil antropometri dan biokimia darah sebagai upaya preventif terhadap penyakit tidak menular di kelurahan Tomang Jakarta Barat. Jurnal Baki Masyarakat Indonesia, 3, 1-9

Tignanelli, C. J., Ingraham, N. E., Sparks, M. A., Reikoff, R., Bezdicek, T., Benson, B. Schacker, T., Chipman, J. G., \& Puskarich, M. A. (2020). Antihypertensive drugs and risk of COVID-19? The Lancet Respiratory Medicine. https://doi.org/10.1016/S2213-2600(20)30153-3

Wenzel, R. P. (2003). Prevention and control of nosocomial infections 4th ed. Lippincott Williams \& Wilkins.

World Health Organization. (2017). Noncommunicable diseases progress monitor, 2017. https://apps.who.int/iris/bitstream/handle/10665/258940/9789241513029eng.pdf? sequence $=1$

World Health Report. (2020). Coronavirus. https://www.who.int/healthtopics/coronavirus. 